\title{
UNMET DENTAL NEEDS AND BARRIERS TO DENTAL CARE AMONG CHILDREN WITH AUTISM SPECTRUM DISORDERS
}

\author{
Bien Lai (BDS)
}

\begin{abstract}
A thesis submitted to the faculty of the University of North Carolina at Chapel Hill in partial fulfillment of the requirements for the degree of Master in the School of Dentistry (Pediatric Dentistry).
\end{abstract}

Chapel Hill

2011

Approved by:

Michael Milano, DMD

Michael Roberts, DDS, MScD

Stephen Hooper, Ph.D. 
(C)2011

Bien Lai, BDS

ALL RIGHTS RESERVED 


\begin{abstract}
BIEN LAI: Unmet Dental Needs and Barriers to Dental Care among Children with Autism Spectrum Disorder
\end{abstract}

(Under the direction of Michael Milano, Michael Roberts and Stephen Hooper)

The purpose of this study is to examine the unmet dental needs and barriers to dental care among children with Autism Spectrum Disorder (ASD) in North Carolina. Mail-in pilot-tested questionnaires were sent to a stratified random sample of 1500 families from the North Carolina Autism Registry. Multivariate logistic regression analysis was used to determine the significance of unmet dental needs and other predictors. Of the 568 surveys returned (RR=38\%), 555 were complete and used. Sixty-five (12\%) children had unmet dental needs. Of 516 children (93\%) who had been to a dentist, $11 \%$ still reported unmet needs. The main barriers to dental care were child's behavior, cost, and lack of insurance. The significant predictor variables of unmet needs were child's behavior $(\mathrm{P}=.01)$, child's dental health $(\mathrm{P}<.001)$, and caregiver's last dental visit greater than 6 months $(\mathrm{P}=.002)$. Type of ASD did not have an effect on having unmet dental needs. 


\section{ACKNOWLEDGEMENTS}

This research study would not have been possible without funding from the North Carolina Translational and Clinical Research Institute (NCTraCS).

To my research committee - Dr Michael Milano, Dr Michael Roberts and Dr Stephen Hooper, thank you for your guidance.

To Ms Renee Clark and Ms Corrie Watson from the Autism Registry of North Carolina, thank you for your support, enthusiasm and help in survey administration and data collection.

To Dr Jessica Lee, thank you for your time and invaluable guidance for the grant application, development of the survey tool, data analysis, and suggestions for the multiple abstracts and thesis writing.

To Dr Kimon Divaris, Dr Ray Tseng, Dr Tina Tseng, Dr Ceib Phillips and Ms Debbie Price, thank you for your help with data analysis and suggestions for the development of the thesis.

To my fellow pediatric dental residents for their moral support and friendship. 


\section{TABLE OF CONTENTS}

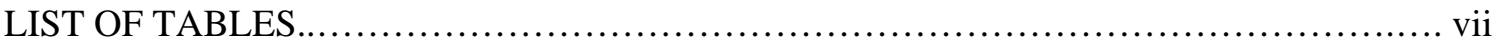

LIST OF ABBREVIATIONS........................................................... viii

Chapter

I. INTRODUCTION

Background and Prevalence.......................................................

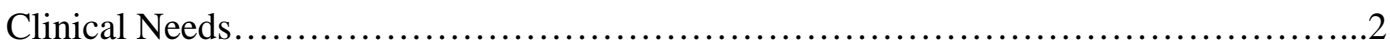

Oral Health Needs....................................................................

Unmet Medical Needs............................................................4

Unmet Dental Needs................................................................

II. $\quad$ SPECIFIC AIMS ....................................................................

III. MATERIALS AND METHODS

Sample....................................................................

Eligibility ................................................................

Measure.....................................................................

Data collection..............................................................9

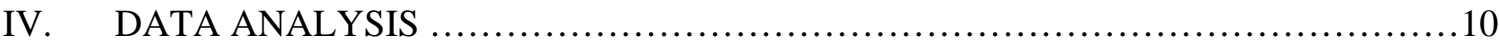

V. RESULTS

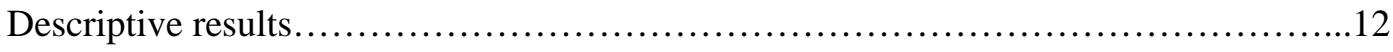

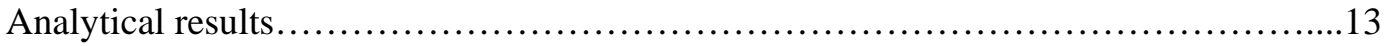

VI. DISCUSSION

Prevalence of unmet dental needs..................................................15

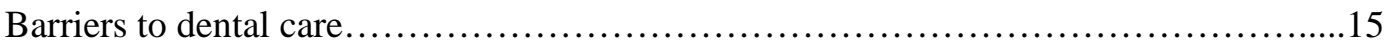


Significance and future directions............................................ 17

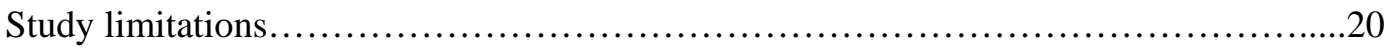

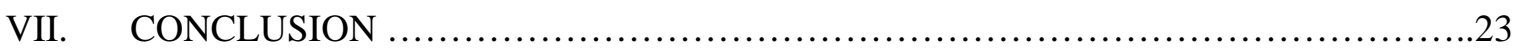

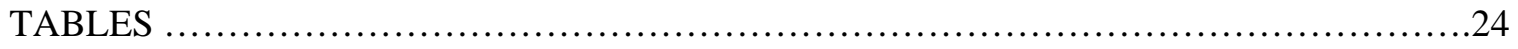

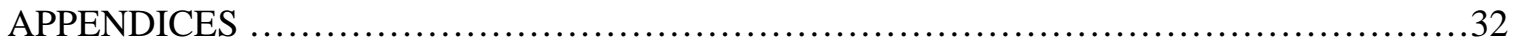

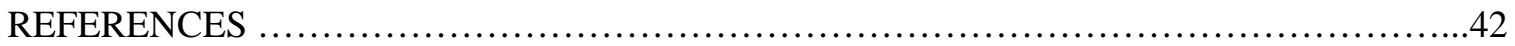




\section{LIST OF TABLES}

Table

1. Demographic characteristics for children with ASD ...............................24

2. Autism-related factors and medical condition...................................... 25

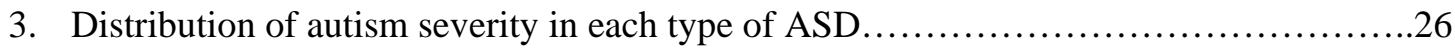

4. Caregiver's perception of child's cooperation and dental health........................26

5. Unmet dental needs and dental visit characteristics..............................27

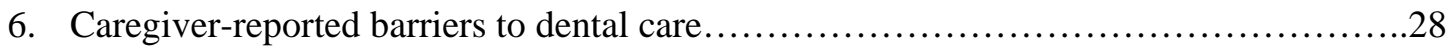

7. Bivariate correlation of independent and dependent variables .......................29

8. Bivariate correlation of independent and dependent variables (continued)................30

9. Factors associated with the odds of having unmet dental need ........................31

10. Characteristics of respondents and non-respondents................................31 


\section{LIST OF ABBREVIATIONS}

ADDM: Autism Development and Disability Monitoring

ADHD: Attention Deficit Hyperactivity Disorder

ASD: Autism Spectrum Disorder

CI: Confidence Interval

CIDD: Carolina Institute for Developmental Disabilities

CDL: Clinical Center for the study of Development and Learning

CSHCN: Children with Special Health Care Needs

NCTraCS: North Carolina Translational and Clinical Research Institute

NHIS: National Health Interview Survey

NICHD: National Institute of Child Health and Human Development

OR: Odds ratio

PDD-NOS: Pervasive Developmental Disorder - Not Otherwise Specified

SAS: Statistical Analysis Systems

SD: Standard Deviation

TEACCH: Treatment and Education of Autistic and Related Communication Handicapped Children

VIF: Variance Inflation Factor 


\section{INTRODUCTION}

\section{Background and prevalence}

Autism spectrum disorders (ASD) is a group of disorders with a wide range of severity, characterized by impairments in language, social interaction, and a markedly restricted repertoire of activities and interests. In the psychiatric nomenclature, the spectrum, consisting of autistic disorder, Asperger's disorder and pervasive developmental disorder - not otherwise specified (PDD-NOS), is grouped under the broad category of pervasive developmental disorders, which also include 2 other conditions - Rett's disorder and childhood disintegrative disorder. (1)

People with autistic disorder are on the more severe end of the autism spectrum distribution, with an onset prior to age 3. Individuals display social awkwardness, resist changes and present with unusual stereotypic behaviors and interests. Comprehension, non-verbal and verbal languages may be affected to different degrees. Presentation ranges from totally non-verbal to poorly-articulated or delayed speech, to well-spoken sentences with an abnormal tinge or echolalia. (1-3)

Individuals with Asperger’s disorder manifest milder symptoms of autistic disorder and are generally high-functioning. They do not display significant language delay or disturbance in cognitive development, and are also capable of acquiring age-appropriate self-help skills and adaptive behavior (other than in social interaction).(3)

PDD-NOS typically includes those individuals whose criteria are not met for a specific pervasive developmental disorder or other psychiatric disorders, such as “atypical autism”, which 
is autism with a late age of onset or atypical symptoms. Individuals with PDD-NOS are less severely affected than those with autistic disorder.(3)

The prevalence of ASD has been increasing over the past few decades. As far back as the 1970s, autism was believed to occur in 4 to 5 per 10,000 children, translating to a prevalence of 0.04-0.05\%. (4, 5) Currently, data from the Autism Development and Disability Monitoring (ADDM) Network estimates that the prevalence of ASD nationally is 1\%. About 1 in 110 US children have some form of ASD. (6) The increase in prevalence may be due to the change in diagnostic criteria, an increase in awareness of autism and an increase in the availability of funding and education services. $(3,7,8)$ At present, the top 3 states with the highest prevalence of ASD are Arizona, Missouri and North Carolina (out of the 11 states in surveillance network). For the purpose of this study, it is noted that North Carolina has the third highest prevalence of ASD with an overall prevalence of 10.4 per 1000 8-year-old children. (6) In addition, North Carolina has the $4^{\text {th }}$ greatest prevalence change (60\%), from 6.5 per 1000 8-year-old children in 2002 to 10.4 per 1000 8-year-old children in 2006. (6)

\section{Clinical needs}

Children with development disabilities often present with complex medical and behavioral issues that could complicate oral health care. These include medications for their comorbid conditions, unique diets, sensory and motor impairments, language deficits, selfinjurious behaviors, physical challenges, greater prevalence of aggressive and disruptive behaviors, anxiety and depression. (9) Rumination and tube feeding were found to be an important factor for the development of dental caries in children with severe motor and intellectual disabilities (10), while orofacial anomalies that accompanied some of the chromosomal disorders could further increase periodontal and caries risks. (9) (11) Children with intellectual disabilities were found to 
have poorer oral health compared to healthy children. (11) The majority of oral health problems were periodontal-related, with high plaque and gingivitis scores. (12-14)

Although Altun et. al. (2010) found that children with ASD had better oral hygiene compared to those with other disabilities (15), many of their clinical features such as sensorimotor deficits (somatosensory, vision, auditory, vestibular function, muscle tone and joint laxity), impaired executive function, attention problems (overfocus or short attention span on certain activities), anxiety and depression, aggression and irritability, difficulties in comprehension and language disabilities(3) may hinder oral health care. These can make oral hygiene routines and behavior management of children with ASD difficult tasks for caregivers and dentists. Furthermore, medical condition such as mental retardation, seizure disorder, attention deficit hyperactivity disorder (ADHD), Fragile X syndrome, and gastro-intestinal problems may coexist in individuals with ASD. (3, 9, 16-18)

Successful management of these children in the dental environment involves preparation of parents and child outside the dental office, scheduling the child at appropriate times of the day, systematic desensitization to the environment, modification and flexibility in common techniques such as positive reinforcement, tell-show-do and negative reinforcement when necessary. $(19,20)$ Above all, having some knowledge and awareness of ASD and its associated features will facilitate the oral health care of this population.

\section{Oral health needs}

To date, few studies have explored the oral health status and dental needs of children with ASD. (20-25) Varies caries susceptibility and prevalence have been reported in different studies. Some revealed similar caries rates for children with ASD compared with a control group (20, 22, $24)$, while others showed a lower caries rate $(22,23)$. A recently published study reported that 
autism may be considered an indicator for high caries risk, with oral hygiene being the most influential risk indicator associated with new caries in children with ASD. (25) In a population of 99 children with ASD, 59\% with poor oral hygiene had new caries compared to $28 \%$ with good or excellent oral hygiene.(25) While this may not be surprising in any population, issues related to oral health care and access to qualified and experienced oral health professionals can create significant risk for these children receiving preventive care.

\section{Unmet medical needs}

The National Health Statement, Healthy People 2020, sets goals for improving access to health care services. (26) One of the proposed targeted areas is to reduce the proportion of individuals that experience difficulties or delays in obtaining necessary medical care, dental care, or prescription medicines. Access to care has been an ongoing problem, especially for children from low-income families, those enrolled in Medicaid, and children with special health care needs (CSHCN). (27-38) Among CSHCN, those with ASD were 2.14 more likely to have unmet needs and less access to important components of healthcare.(39) Long waiting time, cost of care, lack of health insurance, extent of outreach, parental awareness, family commitments, family stress levels, cultural and ethnic disparities, and parental education level were found to be associated with difficulties of accessing treatment services for children with ASD. (40-43) These findings reflect the impact of ASD on access to medical care.

\section{$\underline{\text { Unmet dental needs }}$}

Of all the unmet health needs, the unmet dental need is the most prevalent. $(44,45)$ An estimate of $50 \%$ of children was reported to lack the recommended number of dental visits.(45) Although enrollment in other public health programs (other than Medicaid) has shown improvement in children's access and use of dental care, barriers to dental care remain apparent. $(46,47)$ The majority of studies that examined access to dental care in healthy children were 
focused on Medicaid-eligible children or children from low-income families. The identified barriers include low family income, limited parental educational, poor oral health literacy and awareness about the importance of oral health, negative attitudes of dentist and office staff, ethnic and racial barriers, insurance status, willingness of dentists to treat, and distribution or location of dentists within some states and local communities. (27-29, 31-33, 48)

Although fewer studies have been done on CSHCN, these studies reported that dental care remained to be the most prevalent unmet healthcare need.(49,50) It was reported that $78 \%$ of CSHCN needed dental care in the prior 12 months, while $10.4 \%$ of CSHCN did not receive dental care when needed. (49) Factors associated with higher odds of unmet dental needs for CSHCN were found to be household income, severity of the associated medical condition, lack of insurance, and insurance lapses.(50) A recently published study targeted at a more involved subsample of CSHCN population and reported that $20 \%$ had unmet dental needs. Their findings suggest that the worse overall dental health and greater unmet needs may be due to their greater medical complexity.(51)

Three studies explored unmet dental needs among children with ASD. Data extracted from the 2003 National Survey of Children’s Health (NSCH) did not show a statistical difference for dental care access measures between children with and without ASD. This study, however, did not explore barriers to dental care for children with ASD. (21) In a sample of 55 children with ASD, Brickhouse et al identified difficult behaviors in the dental office and household income as the major barriers to dental care. In addition, it was reported that $24 \%$ of these children did not have scheduled periodic dental care. (52) When the CSHCN population was subdivided, it was revealed that $23 \%$ of the autism group had unmet dental needs although it was not statistically significantly different compared to children with other medical conditions. (51) 


\section{SPECIFIC AIMS}

The primary aim of this study was to survey a sample of caregivers with children with ASD to describe the barriers to dental care and unmet dental needs. The secondary aim was to examine the association of having unmet dental needs and 1) type of ASD and 2) child's perceived behavior in the dental office. 


\section{MATERIALS AND METHODS}

\section{Sample}

The sample was obtained from the Autism Registry of North Carolina, which is part of the core services of the UNC Neurodevelopmental Disorders Research Center. It is a tool for research participant recruitment available to UNC researchers through the National Institute of Child Health and Human Development (NICHD)-funded Intellectual and Developmental Disabilities Research Center at the Carolina Institute for Developmental Disabilities (CIDD). Although the sample was obtained from a single state, North Carolina has a representative population of individuals with ASD due to its availability and diversity of autism-related services for children. (41) The registry database is primarily populated through a collaboration with Division TEACCH (Treatment and Education of Autistic and Related Communication Handicapped Children), which is a state-funded program that provides diagnostic and treatment services for individuals with Pervasive Developmental Disorders in nine centers across North Carolina. It currently has more than 4500 North Carolina residents diagnosed with ASD enrolled; 3441 are under 18 years old. One thousand and five hundred families with children with ASD were selected using a stratified random sampling scheme with weighted allocation.

\section{Eligibility}

The inclusion criteria include families with children age 18 and under who were diagnosed with ASD. If there were more than one child diagnosed with ASD in the family, the oldest child with ASD was considered as the subject of the questionnaire. The sole exclusion criteria was children who were above age 18 . This study was approved by the Institutional Review Board of the University of North Carolina (Chapel Hill). 


\section{Measure}

The survey framework was adapted from the Behavioral Model of Health Services Use. (53) The questionnaire included questions on basic demographics, predisposing factors, enabling factors, and need factors. Additional questions targeted to the ASD population inquired about the type and severity of ASD, the age of diagnosis, number of children diagnosed with ASD in the household, the association with autism-related organizations and the use of educational programs/services. For those who have been to a dentist, dental visit related questions were asked with regards to their child's last dental visit, the main problems faced during the last dental visit, the type of dental office and the frequency of the child's dental visits.

The initial questionnaire was pilot tested by caregivers with children with ASD who presented as patients in the UNC Graduate Pediatric Dentistry clinic. Feedback obtained led to modifications on the structure and wording of the questionnaire. The edited questionnaire and survey administration methods were further discussed and developed with experts from the UNC Odum Institute for the Research of Social Sciences.

To address the study's primary question (to determine the presence of unmet dental needs in children with ASD), the following question was asked:

- During the past 6 months was there a time when you wanted to get dental care for your child but could not get it at that time?

For caregivers who answered "no" to the above question, follow-up descriptive questions that addressed the main barriers to dental care were asked. Multiple answers were allowed for this descriptive section. 
The questionnaire was translated into Spanish. Copies of the English and Spanish questionnaires are included in the Appendix.

\section{$\underline{\text { Data collection }}$}

The survey was conducted from March to May 2010. All mailings were handled by two staff members from the Autism Registry in UNC Neurodevelopmental Disorders Research Center. The investigators did not have access to the mailing list due to confidentiality issues and all questionnaires were anonymous. An identification number was assigned to each questionnaire for the purpose of tracking of non-respondents only. A total of three separate mailing were sent. (54) The first mailing, consisting of an information sheet, the questionnaire and a return envelope, was sent to all selected participants. Two weeks later, a reminder card was sent to all non-respondents. A final mailing, consisting of the questionnaire, information sheet and return envelope, was sent to all non-respondents four weeks after the initial mailing. For Hispanic families, both the English and Spanish questionnaires were mailed. Collection of questionnaires ended at six weeks after the initial mailing. All received questionnaires were scanned by an automatic reader. 


\section{DATA ANALYSIS}

The definition of "having unmet dental needs" was the inability to get dental care when needed in the past six months. The major independent variables were the type of ASD and child's behavior in the dental office. The dependent variable was "having unmet dental needs".

The survey data was managed using Statistical Analysis Systems (SAS®) Version 9.1.3. Descriptive analyses that were calculated include frequencies and percentages for categorical variables, and means and standard deviations for continuous variables. The Fisher's exact test was used for bivariate analyses to examine the relationships between the dependent and independent variables. The statistical significance was set at 0.05 level.

A multivariate regression model was used to examine the relationships between the dependent and independent variables after controlling for potential confounding covariates. The number of independent variables included in the regression model was limited by the sample size. Highly-correlated explanatory variables in the same regression model could create problems in estimation. The variance inflation factor (VIF), a measure of multicollinearity, was use to assess the correlation of the two explanatory variables. Running a regression with the two explanatory variables yielded VIF values of 1.0 for both variables, which was well below the lowest recommended value of concern, a VIF of 2.5.

Odd ratios (ORs) and 95\% confidence intervals (CIs) were used to present the logistic regression analyses. The statistical significance was set at 0.05 level. The final model for the outcome were derived by "child's behavior in dental office" and "type of ASD” as the primary explanatory variables, and employing forward selection to determine if any other explanatory or 
covariate variables were significantly related to the outcome. Four explanatory variables were included in the final model: “child's behavior in dental office”, “type of ASD”, “child’s dental health status”, and "time since caregiver’s last dental visit”.

Child's behavior and child's dental health status mentioned in this study refers to behavior and dental health as perceived by their caregivers respectively. 


\section{RESULTS}

The response rate was 37\% ( $\mathrm{N}=568)$. Six questionnaires were rejected due to scanning errors. Two subjects did not meet the inclusion criteria, while five were excluded because the caregivers did not answer the question that was related to the dependent variable. A total of 555 questionnaires were complete and used in data analysis. Not all respondents answered every question. The missing values were excluded in the denominator for the calculation of percentages.

\section{Descriptive results}

The demographic characteristics of children with ASD and caregiver factors are summarized in Tables 1 . The majority of children were males, white and non-Hispanic. The mean age was 9.9 years old, with a standard deviation (SD) of 3.9 years. Only 3.5\% of the children were not attending school. Slightly more than half of the children had private dental insurance only and approximately $75 \%$ had an average household income of $\$ 35,000$ or greater. The majority of the caregivers were at least high school graduates, with $56.6 \%$ being college graduates. Seventy-five percent of the caregivers reported the last dental visit within the past year.

Information on the autism-related factors and the child's medical condition are summarized in Table 2. Approximately $40 \%$ of the children were diagnosed with autistic disorder and Asperger's disorder respectively. The distribution of autism severity in each type of ASD was presented in Table 3. There were more children with severe ASD in autistic disorder type, while more children were of milder ASD in Asperger's disorder and PDD-NOS types. The mean age of diagnosis was 5.2 years old ( $S D=3.1$ ). Approximately $40 \%$ of the children had some co-existing medical condition, with the majority being psychiatric and behavioral conditions. Attention deficit hyperactivity disorder (ADHD) was the most commonly co-existing medical condition. The 
majority of the children received medical care by family physicians, with $95 \%$ of them having regular care.

As summarized in Table 4, the child's behavior in the dental office was evenly distributed, with approximately $25 \%$ in each behavior category - poor, fair, good, and excellent. Close to $80 \%$ of the caregivers reported that their child's dental health was in good or excellent condition. Child's dental health status mentioned in this study refers to dental health as perceived by their caregivers.

The proportion of children with unmet dental needs and dental visit characteristics was summarized in Table 5. Overall, only $11.7 \%$ of the caregivers reported an unmet dental need in the past 6 months. Although the majority of the children (94.2\%) had been to a dentist, $11 \%$ of these children still reported unmet needs. Among the children who had been to a dentist, about $90 \%$ of them had their last dental visit within the past year and $75 \%$ visited their dentists every 3 to 6 months. The two most common problems at the child's last dental visit were reported to be the child's behavior (29.8\%) and the clinic not accepting Medicaid (21.0\%).

Descriptive data on barriers to dental care is summarized in Table 6. For those who had an unmet dental need in the past 6 months, the most commonly reported barriers were the child's cooperation (60.0\%), cost of care (38.5\%) and lack of dental insurance (23.1\%).

\section{$\underline{\text { Analytical results }}$}

When the relationship of the covariates and the outcome variable were assessed with bivariate analyses, the following variables were significantly associated with having unmet dental care needs (Tables 7 and 8): (1) average household income ( $\mathrm{p}=0.02)$; (2) dental insurance coverage ( $p=0.04)$; (3) caregiver's education level $(\mathrm{p}<0.001)$; (4) child's behavior in dental office 
$(\mathrm{p}<0.001)$; (5) child's dental health status ( $<<0.001)$; (6) caregiver's last dental visit $(\mathrm{p}<0.001)$ and (7) the type of dental office $(\mathrm{p}=0.002)$.

Table 9 shows factors related to having unmet dental needs after multivariate analysis. Children with "good" and "excellent” behavior in dental office were collapsed into one group for the analysis.

Having unmet dental needs was associated with the time since caregiver's last dental visit, specifically more than 6 months to 1 year $(\mathrm{OR}=2.58,95 \% \mathrm{CI}=1.07-6.26, P<.001)$, and more than 1 year to 3 years $(\mathrm{OR}=3.26,95 \% \mathrm{CI}=1.65-6.47, P<.001)$.

Improving behavior in the dental office had a protective effect on having unmet dental needs. Children with fair and good behavior had decreased odds of having unmet dental needs $(\mathrm{OR}=0.41,95 \% \mathrm{CI}=0.19-0.86, P=0.01 ; \mathrm{OR}=0.37,95 \% \mathrm{CI}=0.17-0.80, P=0.01)$ compared to those with poor behavior in the dental office.

Having good dental health status also had a protective effect. Children who were perceived to have good dental health had decreased odds of having unmet dental needs compared to those with poor perceived dental health status (OR=0.17, 95\% CI=0.07-0.39, $P<0.001)$.

Children with a diagnosis of either Asperger's syndrome or PDD-NOS was not significantly associated with having unmet dental needs compared to those with autistic disorder $(P=0.89)$. 


\section{DISCUSSION}

\section{Prevalence of unmet dental needs}

Dental care remains the most prevalent unmet healthcare needs for children with and without special needs.(34, 48) This study reported $12 \%$ of children with ASD had unmet dental needs in the past 6 months. The prevalence was higher compared to previous studies. $(34,49)$. Data extracted from a 4-year National Health Interview Survey (NHIS) (1993-1996) revealed that $5.3 \%$ of children had unmet dental needs in the past year (44), while $10.4 \%$ of CSHCN reported unmet needs in a separate survey.(49) Our study was the second study that focused on unmet dental needs in children with ASD. Brickhouse reported 19\% of children with ASD having unmet dental needs in the past 12 months, which was higher than the current study. The difference could be due to sampling from a different population and having a larger sample size in our study. Nelson et al subdivided their sample of CSHCNs and reported that 23\% of children with autism had unmet dental needs.(51) However, this was not found to be statistically significantly different from CSHCNs with other conditions. The higher prevalence of unmet dental needs in their study could be due to a more involved specifically targeted population of CSHCNs, who presented with greater medical complexity.

\section{Barriers to dental care}

Our findings revealed that although the majority of children with ASD (94\%) had been to a dentist, $11 \%$ still reported unmet dental needs. This suggests that unmet dental needs still exist although children with ASD seemed to have good access to dental care, as indicated by the reported dental visits. The main cited barriers to dental care were the child's behavior, cost of dental care and lack of dental insurance. These were consistent with other national studies 
reporting on the general child population and CSHCN. Limitations attributed to disability and difficult behaviors hindered children from getting dental care when needed in addition to the commonly reported barriers. $(49,52)$ In this study, the child's behavior was the major barrier to dental care and the most frequently cited problem during the child's last dental visit. The child's behavior in the dental office was also found to be associated with having unmet dental needs in the bivariate and multivariate analyses. Children with poor perceived behavior in the dental office had higher odds of having unmet dental needs after controlling for effects from covariates. Our findings were not surprising in that children with ASD possessed many behavioral clinical features such as sensorimotor deficits, impaired executive function, attention problems, aggression, irritability, difficulties in comprehension and language disabilities, that could complicate oral health care at home and in the dental office.

Although a previous study (52) had reported on unmet dental needs among children with ASD, our study was the first to examine the relationship between unmet dental needs and the type of ASD. Children with different types of ASD present with unique clinical features and the severity of the condition within each type of ASD also differs among individuals. In contrast to our hypothesis that a different degree of dental needs may exist among children with different types of ASD, our findings did not detect any differences in having unmet dental needs. The effect of ASD on unmet dental needs may be diluted by the variability of severity within each type of ASD. The degree of severity in one type of ASD does not correlate with another type. For example, a child with mild autistic disorder differs in behavior compared to a child with mild Asperger's syndrome.

The finding that children with good perceived dental health had lower odds of having unmet dental need was not surprising because children with better dental health would be less likely to have dental needs. However, it must be noted that the dental health status was self- 
reported by caregivers, and the definitions of poor, fair and good dental health were not specified in the questionnaire. A clinical dental examination was not performed to verify caregiver's opinion of the child's dental health status. Caregiver's perception on the child's dental health may differ from the actual dental health, and could be affected by their knowledge, attitude, awareness of oral health, and previous dental experience. In addition, time since caregiver's last dental visit was found to have an effect on having unmet dental needs. Children whose caregivers had their last dental visits more than six months ago had higher odds of having unmet dental needs. This relationship reinforced the earlier assumption that caregiver's attitude may have affected the likelihood of getting dental needs met for children with ASD. Caregivers who had their dental visit less than six months ago may be more conscientious in maintaining good dental health, and are more likely to bring their children for timely and regular dental visits, therefore less unmet dental needs.

\section{Significance and future directions}

The child's behavior was found to be the major barrier to care in this study and previous studies.(50, 52) Our study reinforces the importance of behavior management of children with ASD in the dental office. Future research should be focused on the following areas: child, caregiver, dental and medical health care providers.

\section{Child}

Studies investigating behavior management or modification interventions for children with different type of ASD before and during dental visit may provide insights into helping these children cope with dental procedures. Children with autism may be acclimatized to the dental environment after a certain number of dental visits or caregivers may decide to decrease the frequency of dental visits due to the children's poor behavior in previous dental visits. Prospective clinical studies examining changes in cooperation with dental procedures in children with autism 
over a certain time period may provide an insight on the effect of behavior management intervention and recommendations for dental visits. This may serve as a basis for professional recommendations and for parental counseling. In addition, the influence of child's age on behavior may be different among children with and without ASD. Behavior management of younger children with ASD may be relatively easier (employing physical active restraint if child's behavior is challenging in the dental office), compared to older children with ASD (when physical restraint may be difficult, and alternative pharmacological behavior management methods have to be considered). A prospective or cross-sectional clinical study may be done to examine the relationship between child’s age and behavior management strategies.

\section{Caregiver}

Caregiver's perception of behavior may under-estimate or over-estimate child's actual behavior, especially for those who have never been to the dentist. In addition, child may respond differently to different dental procedures. Future studies may examine the association between the caregiver's perception of child's behavior in the dental office with the actual behavior of the child as assessed by the clinicians.

\section{Dental health care providers}

It is important for dental health care providers to be familiar with ASD and its associated clinical manifestation so that they tailor to their patients' individual needs and use the appropriate behavior management strategies to garner maximum cooperation.

Training in caring for special needs patients seems to be inadequate. A survey of dental school programs revealed that only $64 \%$ offered a separate course about special needs patients. (55) Wolff et al reported 50.8\% of dental students surveyed had no clinical experience in caring for patient with mental retardation and $60 \%$ reported having little or no confidence in providing 
care.(56) In a recently published study regarding pediatric and general dentists' professional attitudes towards patient with ASD, a majority of the respondents indicated that they received inadequate training in their predoctoral dental education in treating patient with ASD. The study also found that the quality of pediatric dentists' education experiences correlated with the frequency of appropriate behavior management strategy used when treating patients with ASD.(57)

Pilot training programs for caring of patients with special needs should be incorporated into the dental school curriculum. Connections may be established for dental students to go on rotations at off-site institutions or hospitals to enhance their clinical experience in caring for patients with special needs. General and pediatric dentists should be encouraged to attend continual education for updates on current evidence and behavior management of children with special needs in dental settings.

\section{Medical health care providers}

The majority of the children (95\%) in this study had regular medical care by their family physicians, while $75 \%$ had regular dental visit at least every six months. Although this study did not investigate unmet medical needs among children with ASD, the findings seemed to suggest that this sample of children with ASD had more encounters with physicians than dental professionals. An interdisciplinary team approach with the child's physician may help to overcome or manage the behavior of the child with ASD, which was reported to be the major barrier to dental care and most frequently cited problem at the child's last dental visit. An oral health assessment may be incorporated in a physician's visit and an appropriate referral base or connection may be established. Pilot programs involving individualized interventions with a team approach may be designed for each child to help them cope with dental procedures, and improve oral health care in these children. 
Future cross-sectional surveys should sample children across the nation, and to be administered to families with children with and without ASD, so that results could be generalized to the general population. The questionnaires may also be linked to clinical oral examinations of the children so that the actual dental health status can be determined by professionals.

\section{$\underline{\text { Study limitations }}$}

We acknowledge several limitations when conducting this research study. One of the limitations of this study is the response rate. The average reported mail-in response rate of the Autism Registry of North Carolina was 30\%. Although we tried to increase the response rate through three separate mailings, the current study had a response rate of $38 \%$. The relatively low response rate could be due to the length of the questionnaire.

We attempt to analyze the difference between respondents and non-respondents using characteristics provided from the Autism Registry of North Carolina. (Table 10) Families who were from Raleigh and east of Raleigh were categorized as "east”, those from west of Raleigh were categorized as "west". Although the bivariate analyses using chi-square tests revealed that respondents and non-respondents were statistically significantly different with regards to the child' race $(P=0.004)$, the association between child's race and having unmet dental needs (the outcome variable) was not statistically significant $(P=0.85)$ as reported in the result section. Child's gender $(P=0.52)$ and location $(P=0.63)$ in North Carolina were not significantly different among respondents and non-respondents. Therefore, with the limited information available for comparison between respondents and non-respondents, we believe that the respondent population is representative of the 1500 families who were randomly selected for this study. 
Selection bias is the major limitation in this study. Families who have registered with the autism registry may have better access and utilization to health care resources. Because the questionnaires were mailed through the autism registry, institutionalized children and those who were not registered with the registry were omitted in the study. In addition, those who are illiterate or do not understand English or Spanish would not be able to complete the survey. These individuals may be the ones who truly have difficulties in accessing health care and have unmet needs. As such, outcome of this study may not be generalized to the whole population of individuals with ASD. The overall prevalence of unmet dental needs in children with ASD may be underestimated.

There could also be an under-estimation or over-estimation of the unmet need prevalence as a result of having a different time period of six months, compared to those in previous studies where they looked at unmet needs in the past twelve months. An underestimation could occur because children with unmet dental needs beyond six months were not included in the study. More children could have unmet needs between the past six to twelve months. On the other hand, there might be an overestimation of unmet needs because some children could have seen the dentist in the past six to twelve months. Fewer children would have unmet dental needs in this circumstance. The recommended frequency of dental visit for children and adolescents was twice yearly (every six months) based on individual's risk status. (2) Children with special health care needs were considered high-risk individuals who required dental visits at least every six months. Therefore, a six-month period was chosen for this questionnaire.

As with other self-reported cross-sectional studies, we acknowledge the reporting bias with regards to the reliance on caregivers' reports. The caregiver's assessment of behavior may or may not represent the actual behavior of the child, especially when each child differs in behavior under different situations and interaction with other individuals. In addition, the caregiver's 
assessment may not be accurate for those children who had not been to the dentist. We also did not specify the dental procedures performed. There would likely be a difference in response to dental treatment, depending on the type of dental procedures performed. Without clinical oral examinations and assessments in the dental office, caregivers' reports may not accurately reflect the true dental needs, dental health status and behavior of the child in dental office. In addition, there are many different dental needs relating to oral hygiene, caries, trauma or orthodontics. We did not identify the type of dental needs that were needed in this study.

Although this study was designed to focus on children with ASD and included questions that examined factors that may have possible effect of autism on having unmet dental needs, it was generally a descriptive study and did not have utilize a control group for comparison. 


\section{CONCLUSION}

Although the majority of children with ASD had been to a dentist, $12 \%$ reported unmet dental needs in the past six months. The major barrier to dental care appeared to be child's behavior. The type of ASD was not associated with unmet dental needs. Strategies to further minimize unmet dental needs should focus on increasing patient cooperation in the dental office and consider an interdisciplinary team approach with the child's physician. 


\section{TABLES}

Table 1. Demographic characteristics for children with ASD ( $=555)$

\begin{tabular}{|c|c|c|c|c|c|c|}
\hline & $\mathbf{N}$ & $\%$ & & & $\mathbf{N}$ & $\%$ \\
\hline Sex & & & \multicolumn{2}{|c|}{ Type of dental insurance } & & \\
\hline Male & 464 & 83.6 & \multicolumn{2}{|l|}{ Private only } & 301 & 54.4 \\
\hline Female & 91 & 16.4 & \multicolumn{2}{|l|}{ Medicaid only } & 159 & 28.8 \\
\hline & & & \multicolumn{2}{|l|}{ Medicaid and Private } & 18 & 3.3 \\
\hline Race & & & \multicolumn{2}{|l|}{ None } & 75 & 13.6 \\
\hline Black & 43 & 7.8 & \multicolumn{2}{|l|}{ Missing } & 2 & - \\
\hline White & 466 & 84.9 & & & & \\
\hline Other & 40 & 7.3 & \multicolumn{2}{|l|}{ Type of community } & & \\
\hline \multirow[t]{2}{*}{ Missing } & 6 & - & \multicolumn{2}{|l|}{ Rural } & 182 & 33.6 \\
\hline & & & \multicolumn{2}{|l|}{ Suburban } & 274 & 50.7 \\
\hline Ethnicity & & & \multicolumn{2}{|l|}{ Urban/City } & 85 & 15.7 \\
\hline Hispanic or Latino & 22 & 4.0 & \multicolumn{2}{|l|}{ Missing } & 14 & - \\
\hline Not Hispanic or Latino & 529 & 96.0 & & & & \\
\hline \multirow[t]{2}{*}{ Missing } & 4 & & \multicolumn{4}{|c|}{ Last dental visit for caregiver } \\
\hline & & & \multicolumn{2}{|l|}{$\leq 6$ months } & 367 & 66.1 \\
\hline Average household income & & & \multicolumn{2}{|l|}{6 months -1 year } & 51 & 9.2 \\
\hline$<\$ 35,000$ & 144 & 26.6 & \multicolumn{2}{|c|}{$>1-3$ years } & 81 & 14.6 \\
\hline$\$ 35,000-74,999$ & 199 & 36.7 & \multicolumn{2}{|c|}{$\begin{array}{l}\text { > } 3 \text { years/never been/do not } \\
\text { know or remember }\end{array}$} & 56 & 10.1 \\
\hline$\geq \$ 75,000$ & 199 & 36.7 & & & & \\
\hline \multirow[t]{2}{*}{ Missing } & 13 & - & \multicolumn{4}{|l|}{ School attendance } \\
\hline & & & \multicolumn{2}{|l|}{ Yes } & 529 & 96.5 \\
\hline Caregiver's education & & & \multicolumn{2}{|l|}{ No } & 19 & 3.5 \\
\hline Did not complete HS & 18 & 3.3 & \multirow{2}{*}{\multicolumn{2}{|c|}{ Missing }} & 7 & - \\
\hline HS graduate & 221 & 40.1 & & & & \\
\hline College graduate & 312 & 56.6 & Age of child (years) & Mean (SD) & $\mathrm{Mec}$ & (Range) \\
\hline Missing & 4 & - & Missing $=2$ & 9.9(3.9) & 10. & $.0-18.0)$ \\
\hline
\end{tabular}


Table 2. Autism-related factors and medical condition $(\mathrm{N}=555)$

\begin{tabular}{|c|c|c|}
\hline & $\mathbf{N}$ & $\%$ \\
\hline \multicolumn{3}{|l|}{ Type of ASD } \\
\hline Autism Disorder & 216 & 38.9 \\
\hline Asperger's syndrome & 210 & 37.8 \\
\hline PDD-NOS & 129 & 23.3 \\
\hline \multicolumn{3}{|c|}{ No. of children in household with ASD } \\
\hline 1 & 513 & 92.4 \\
\hline More than 1 & 42 & 7.6 \\
\hline \multicolumn{3}{|l|}{ Other Medical Conditions } \\
\hline Yes & 230 & 41.5 \\
\hline No & 324 & 58.5 \\
\hline Missing & 1 & \\
\hline \multicolumn{3}{|l|}{ Type of Medical Conditions* } \\
\hline ADHD & 89 & 39.0 \\
\hline Behavioral/ psychiatric conditions & 47 & 20.6 \\
\hline Cerebral palsy/seizure disorders & 15 & 6.6 \\
\hline Other & 77 & 33.8 \\
\hline \multicolumn{3}{|l|}{ Medical care by family physicians } \\
\hline Yes & 535 & 97.0 \\
\hline No & 16 & 3.0 \\
\hline Missing & 4 & \\
\hline \multicolumn{3}{|l|}{ Reasons for seeing family physicians } \\
\hline Regular check-ups only & 82 & 15.6 \\
\hline Illness only & 27 & 5.2 \\
\hline Both & 416 & 79.2 \\
\hline Missing & 30 & \\
\hline \multicolumn{3}{|l|}{ Child registered with organization $^{\dagger}$} \\
\hline Autism Society of NC & 333 & 60.0 \\
\hline TEACCH & 495 & 89.2 \\
\hline CDL & 18 & 3.2 \\
\hline Age of diagnosis & Mean (SD) & Median (Range) \\
\hline Missing $=4$ & $5.2(3.1)$ & $4.4(1.0-16.0)$ \\
\hline
\end{tabular}


Table 3. Distribution of autism severity in each type of ASD $(\mathrm{N}=555)$

\begin{tabular}{lrc}
\hline & N & \% \\
\hline Autism Disorder & & \\
Mild & 91 & 46.7 \\
Moderate & 77 & 39.5 \\
Severe & 27 & 13.8 \\
& & \\
Asperger's syndrome & & \\
Mild & 129 & 66.8 \\
Moderate & 58 & 30.1 \\
Severe & 6 & 3.1 \\
& & \\
PDD-NOS & & \\
Mild & 73 & 62.9 \\
Moderate & 37 & 31.9 \\
Severe & 6 & 5.2 \\
& & \\
\hline
\end{tabular}

Table 4. Caregiver's perception of child's cooperation and dental health ( $N=555)$

\begin{tabular}{lrr}
\hline & $\mathbf{N}$ & $\mathbf{\%}$ \\
\hline Child's perceived cooperation in dental office & & \\
Poor & 150 & 27.1 \\
Fair & 137 & 24.7 \\
Good & 142 & 25.6 \\
Excellent & 125 & 22.6 \\
Missing & 1 & \\
& & \\
Child's perceived dental health status & & 3.8 \\
Poor & 21 & 15.0 \\
Fair & 83 & 81.2 \\
Good-Excellent & 450 & \\
Missing & 1 & \\
\end{tabular}


Table 5. Unmet dental needs and dental visit characteristics $(\mathrm{N}=555)$

\begin{tabular}{lrr}
\hline & N & \% \\
\hline Child needed dental care but did not get it in the past 6 months & 65 & 11.7 \\
Yes & 490 & 88.3 \\
No & & \\
Child ever been to a dentist & & \\
Yes & 523 & 94.2 \\
No & 32 & 5.8
\end{tabular}

Child's frequency of dental visit*

$\begin{array}{lll}\text { Every } 3 \text { to } 6 \text { months } & 391 & 75.2\end{array}$

$\begin{array}{lll}\text { Once a year } & 72 & 13.8\end{array}$

Only when pain occurs/other $\begin{array}{ll}72 & 11.0\end{array}$

Missing 35

Child's last dental visit*

$\begin{array}{lrr}\leq 6 \text { months } & 390 & 74.6\end{array}$

$\begin{array}{lll}6 \text { months to } 1 \text { year } & 56 & 10.7\end{array}$

1 year to 3 years $\quad 54 \quad 10.3$

$>3$ years/do not know or remember $\quad 23 \quad 4.4$

Missing $\quad 32$

Type of dental office*

$\begin{array}{lll}\text { General practice } & 195 & 37.6\end{array}$

Pediatric Dentistry $\quad 298 \quad 57.5$

Other $\quad 25 \quad 4.8$

$\begin{array}{ll}\text { Missing } & 37\end{array}$

Main problems at last dental visit* ${ }^{\dagger}$

Dentist/assistant was not able to handle my child $\quad 50 \quad 9.6$

Dentist/assistant did not treat me or my child with respect $\quad 22 \quad 4.2$

Dentist did not treat young children $\quad 5 \quad 1.0$

Dentist did not treat special needs children $\quad 43 \quad 8.2$

$\begin{array}{lll}\text { My child could not cooperate } & 156 & 29.8\end{array}$

$\begin{array}{lll}\text { Clinic did not accept Medicaid } & 11 & 21.0\end{array}$

Clinic was not "special-needs” friendly $\quad 39 \quad 7.5$

$\begin{array}{lrr}\text { Child's anxiety } & 19 & 3.6\end{array}$

$\begin{array}{lrr}\text { None } & 180 & 34.4\end{array}$

\footnotetext{
* Only those who answered "yes" to the question " Have your child been to a dentist?" responded.

${ }^{\dagger}$ Percentage calculated out of those who had been to a dentist $(\mathrm{N}=523)$; multiple answers were allowed for the question.
} 
Table 6. Caregiver-reported barriers to dental care $(\mathrm{N}=65)$

\begin{tabular}{lrr}
\hline & $\begin{array}{c}\text { Main reasons why child could not get } \\
\text { care when he/she needed dental care } \\
\text { during the past 6 months* }\end{array}$ \\
\hline Could not afford it & N & \% \\
No insurance & 25 & 38.5 \\
Dentist did not accept Medicaid/insurance & 15 & 23.1 \\
No dentist available & 6 & 9.2 \\
Transportation problem & 11 & 16.9 \\
Health of another family member & 6 & 9.2 \\
Other things in the family to be taken care of & 5 & 7.7 \\
Hours not convenient due to work & 7 & 10.8 \\
Wait too long in clinic/office & 8 & 12.3 \\
Difficulty in getting appointment & 9 & 13.8 \\
Did not know where to go & 12 & 18.5 \\
Didn't like/trust/believe in dentists & 7 & 10.8 \\
Patient's medical condition & 5 & 7.7 \\
Language barrier & 1 & 3.1 \\
Child was uncooperative & 1 & 1.5 \\
Child was too young & 39 & 60.0 \\
Baby teeth will “fall out” by themselves soon & 3 & 4.6 \\
Child's oral condition was very good and did & - & - \\
not need to see a dentist & - & - \\
Child's dental condition was not serious & - & - \\
enough to see a dentist & & \\
\hline
\end{tabular}

* Multiple answers were allowed for the question. 
Table 7. Bivariate correlation of independent variables and outcome variables $(\mathrm{N}=555)$

\begin{tabular}{|c|c|c|c|}
\hline & \multicolumn{2}{|c|}{$\begin{array}{l}\text { Child needed dental care but } \\
\text { did not get it in the past six } \\
\text { months } N(\%)\end{array}$} & \multirow[t]{2}{*}{$P$-value } \\
\hline & Yes & No & \\
\hline $\begin{array}{l}\text { Diagnosis of Child } \\
\text { Autism Disorder } \\
\text { Asperger's Syndrome } \\
\text { PDD-NOS }\end{array}$ & $\begin{array}{l}28(43.1) \\
22(33.9) \\
15(23.0)\end{array}$ & $\begin{array}{l}188(38.4) \\
188(38.4) \\
114(23.2)\end{array}$ & 0.72 \\
\hline $\begin{array}{l}\text { No. of children diagnosed with ASD } \\
1 \\
\text { More than } 1\end{array}$ & $\begin{array}{r}63(96.9) \\
2(3.1)\end{array}$ & $\begin{array}{r}450(91.8) \\
40(8.2)\end{array}$ & 0.21 \\
\hline $\begin{array}{l}\text { Presence of other medical conditions } \\
\text { Yes } \\
\text { No }\end{array}$ & $\begin{array}{l}30(46.1) \\
35(53.9)\end{array}$ & $\begin{array}{l}200(40.9) \\
289(59.1)\end{array}$ & 0.42 \\
\hline $\begin{array}{l}\text { Type of community } \\
\text { Rural } \\
\text { Suburban } \\
\text { Urban/City }\end{array}$ & $\begin{array}{r}28(44.4) \\
30(47.6) \\
5(8.0)\end{array}$ & $\begin{array}{r}154(32.2) \\
244(51.1) \\
80(16.7)\end{array}$ & 0.07 \\
\hline $\begin{array}{l}\text { Ethnicity } \\
\text { Hispanic } \\
\text { Non-Hispanic }\end{array}$ & $\begin{array}{r}1(1.5) \\
64(98.5)\end{array}$ & $\begin{array}{r}21(4.3) \\
465(95.7)\end{array}$ & 0.50 \\
\hline $\begin{array}{l}\text { Race } \\
\text { Black } \\
\text { White } \\
\text { Others }\end{array}$ & $\begin{array}{r}6(9.2) \\
55(84.6) \\
4(6.2)\end{array}$ & $\begin{array}{r}37(7.6) \\
411(84.9) \\
36(7.4)\end{array}$ & 0.85 \\
\hline $\begin{array}{l}\text { Average household income } \\
<\$ 35,000 \\
\$ 35,000-\$ 74,999 \\
\geq \$ 75,000\end{array}$ & $\begin{array}{l}26(40.0) \\
23(35.4) \\
16(24.6)\end{array}$ & $\begin{array}{l}118(24.7) \\
176(36.9) \\
183(38.4)\end{array}$ & $0.02^{*}$ \\
\hline $\begin{array}{l}\text { School attendance } \\
\text { Yes } \\
\text { No }\end{array}$ & $\begin{array}{r}59(93.7) \\
4(6.3)\end{array}$ & $\begin{array}{r}470(96.9) \\
15(3.1)\end{array}$ & 0.26 \\
\hline $\begin{array}{l}\text { Dental insurance coverage } \\
\text { Private only } \\
\text { Medicaid only } \\
\text { None } \\
\text { Medicaid and private }\end{array}$ & $\begin{array}{r}25(39.0) \\
24(37.5) \\
11(17.2) \\
4(6.3)\end{array}$ & $\begin{array}{r}276(56.4) \\
135(27.6) \\
64(13.1) \\
14(2.9)\end{array}$ & $0.04^{*}$ \\
\hline Age (mean(SE); years) ${ }^{\ddagger}$ & $8.3(0.5)$ & $9.6(0.2)$ & 0.18 \\
\hline Age of diagnosis (mean(SE); years) ${ }^{\ddagger}$ & $4.0(0.4)$ & $5.0(0.1)$ & 0.31 \\
\hline
\end{tabular}

*Statistically significant level at 0.05 .

† "Not sure" category was not included in bivariate analysis.

${ }_{\ddagger}$ T-test used for continuous variables. 
Table 8. Bivariate correlation of independent variables and outcome variables $(\mathrm{N}=555)$

\begin{tabular}{|c|c|c|c|}
\hline & \multicolumn{2}{|c|}{$\begin{array}{l}\text { Child needed dental care but } \\
\text { did not get it in the past six } \\
\text { months } N(\%)\end{array}$} & \multirow[t]{2}{*}{$\boldsymbol{P}$} \\
\hline & Yes & No & \\
\hline Caregiver's education level & & & $<.001^{*}$ \\
\hline Did not complete high school & 1(1.6) & 17(3.5) & \\
\hline High school graduate & $43(67.2)$ & $178(36.6)$ & \\
\hline College graduate & $20(31.3)$ & 292(59.9) & \\
\hline $\begin{array}{l}\text { Caregiver's perception of child's } \\
\text { behavior in dental office }\end{array}$ & & & $<.001^{*}$ \\
\hline Poor & $35(53.9)$ & $115(23.5)$ & \\
\hline Fair & $14(21.5)$ & $123(25.2)$ & \\
\hline Good & $8(12.3)$ & $134(27.4)$ & \\
\hline Excellent & $8(12.3)$ & 117(23.9) & \\
\hline $\begin{array}{l}\text { Caregiver's perception of child's status } \\
\text { of dental health }\end{array}$ & & & $<.001^{*}$ \\
\hline Poor & $5(7.6)$ & 16(3.2) & \\
\hline Fair & $25(38.5)$ & 58(11.9) & \\
\hline Good-Excellent & $35(53.9)$ & $415(84.9)$ & \\
\hline Missing=1 & & & \\
\hline Last dental visit for caregiver & & & $<.001^{*}$ \\
\hline$\leq 6$ months & $26(40.0)$ & $341(69.6)$ & \\
\hline 6 months - 1 year & $10(15.3)$ & $41(8.4)$ & \\
\hline $1-3$ years & $22(33.9)$ & $59(12.0)$ & \\
\hline$>3$ years & $7(10.8)$ & $49(10.0)$ & \\
\hline Type of dental office & & & $0.002^{*}$ \\
\hline General practice & 19(33.9) & 176(38.1) & \\
\hline Pediatric dentistry & $28(50.0)$ & $270(58.4)$ & \\
\hline Others & $9(16.1)$ & $16(3.5)$ & \\
\hline
\end{tabular}

*Statistically significant level at 0.05 . 
Table 9. Factors associated with the odds of having unmet dental need in children with ASD. ( $\mathrm{N}=555)$

\begin{tabular}{lccc}
\hline & OR & $\mathbf{9 5 . 0 \%}$ C.I. & P-value \\
\hline Perceived behavior in dental office & & - & $0.01^{*}$ \\
Poor & reference & $0.19-0.86^{*}$ & \\
Fair & 0.41 & $0.17-0.80^{*}$ & \\
Good & 0.37 & & \\
& & & 0.89 \\
Type of ASD & & & \\
Autistic disorder & reference & $0.58-2.31$ & \\
Asperger's syndrome & 1.16 & $0.54-2.51$ & \\
PDD-NOS & 1.17 & & \\
& & & \\
Caregiver's last dental visit & & & \\
$\leq 6$ months & reference & & \\
$>$ 6 months to 1 year & 2.58 & $1.07-6.26^{*}$ & \\
$>1$ year to 3 years & 3.26 & $1.65-6.47^{*}$ & $0.002^{*}$ \\
$>$ 3years/ do not remember & 0.79 & $0.28-2.27$ & \\
& & & \\
Dental health status of child & & & \\
Poor & reference & & \\
Fair & 0.66 & $0.33-1.30$ & \\
Good & 0.17 & $0.07-0.39^{*}$ & \\
\hline
\end{tabular}

Parameters are odd ratio (OR) and 95\% confidence interval (CI).

*Statistically significant level at 0.05 .

Table 10. Bivariate correlation of variables between respondents and non-respondents $(\mathrm{N}=1500)$

\begin{tabular}{|c|c|c|c|}
\hline & $\begin{array}{c}\text { Respondent } \\
\mathrm{N}(\%)\end{array}$ & $\begin{array}{c}\text { Non-respondent } \\
\mathrm{N}(\%)\end{array}$ & $P$ \\
\hline $\begin{array}{l}\text { Child's gender } \\
\text { Male } \\
\text { Female } \\
\text { Missing=1 }\end{array}$ & $\begin{array}{r}488(83.7) \\
95(16.3)\end{array}$ & $\begin{array}{l}778(84.9) \\
138(15.1)\end{array}$ & 0.52 \\
\hline $\begin{array}{l}\text { Child's race } \\
\text { White } \\
\text { Non-white } \\
\text { Missing=65 }\end{array}$ & $\begin{array}{r}463(82.4) \\
99(17.6)\end{array}$ & $\begin{array}{l}664(76.1) \\
209(23.9)\end{array}$ & $0.004^{*}$ \\
\hline $\begin{array}{l}\text { Location in North Carolina } \\
\text { East } \\
\text { West }\end{array}$ & $\begin{array}{l}266(45.6) \\
317(54.4)\end{array}$ & $\begin{array}{l}430(46.9) \\
487(53.1)\end{array}$ & 0.63 \\
\hline
\end{tabular}

"Statistically significant level at 0.05 . 


\section{Appendix A: Sample Questionnaire (English)}

UNC DEPARTMENT OF PEDIATRIC DENTISTRY

Access to Dental Care for Children with Autistic Spectrum Disorder

INSTRUCTIONS: Please use pen to complete forms. Fill in circles completely for the most appropriate option or fill in the blanks as needed. Please fill in only ONE option for each question unless otherwise specified.

The survey should be filled out by the primary caregiver. The primary caregiver is defined as the adult responsible for coordinating the dental care of the child, as based on self-report, defined as a parent, grandparent, aunt, uncle, or guardian. When multiple individuals are responsible for the child, the individual who considers himself or herself the child's primary caregiver for oral health-related matters will be used. All subsequent reference to caregiver will follow this definition.

1. What is your relationship to the child? (Please choose ALL that apply)
O Parent
$\bigcirc$ Legal Guardian
Grandparent
Other (please specify):

2. How many children under 18 years old live in your household? If none, record zero.

\section{Are there any children in your household who are diagnosed with Autism Spectrum Disorder?}

$\mathrm{O}$ Yes $\quad \mathrm{No}$ (Thank you for looking at the survey This survey is only for households with autistic children. Please return the papers in the return envelope.)

4. How many of your children have a diagnosis of Autism Spectrum Disorder (ASD)? Write the number in the box

5. Which of the following diagnoses has been made for your child? (If you have more than one child with ASD, answer for the oldest one.)

$\bigcirc$ Autism Disorder (Classic Autism)

O Pervasive Developmental Disorder - Not otherwise specified (PDD-NOS)

6. If you have more than one child with ASD, what is the diagnosis of the next oldest child?

O Only one child affected - Not applicable $\quad$ Autism Disorder $\quad$ O Asperger's syndrome $\quad$ PDD-NOS

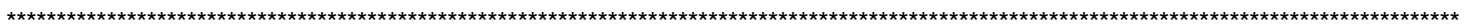

The rest of the questions relate to the oldest child with ASD - the child in question 5.

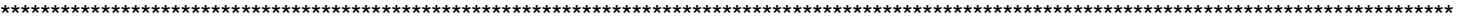

7. What is the current severity of the ASD?

Mild $\bigcirc$ Moderate $\bigcirc$ Severe $\bigcirc$ Not sure

8. What is the age of your child?

years of age (round to the nearest year)

9. At what age was the ASD diagnosis made?

years of age (round to the nearest year)

10. Does your child have any other medical condition?

O No

$\mathrm{O}$ Yes (Please specify) 


\section{Is your child currently taking any prescribed medications? \\ O No \\ Yes (Please name the medication(s) and state what condition(s) they are for)}

12. Has your child taken any (other) prescribed medication in the past?

No

Yes (Please name the medication(s) and state what condition(s) they are for)

13. Does your child see a family physician for medical care?

Yes $\quad$ No (Please skip to Question 15)

14 . Why does your child see a family physican?

Regular checkups $\bigcirc$ Illness only $\bigcirc$ Both

15. Is your child registered with any of the following organizations? (Please choose ALL that apply)
Autism Society of North Carolina
$\mathrm{O}$ TEACCH

Clinical Center for the Study of Development and Learning

Other organizations related to child's ASD condition (Please specify)

16. Does your child attend school (including preschool)?

$\bigcirc$ Yes $\quad$ No (Please skip to Question 18)

17. What educational services does your child receive in school? (Please choose ALL that apply)
O None
$O$ Individualised Educational Program
$\bigcirc$ Inclusion
O Special
$\bigcirc$ Community Alternative Program (CAP)
Other (Please specify)

18. What is your child's educational level?
Too young for school
Pre-school or Kindergarten
7th to 9th grade
10th to 12th grade
1st to 3rd grade
4th to 6th grade
Withdrawn from school

19. Where does your child live? $\bigcirc$ At home $\bigcirc$ Institution $\bigcirc$ Group Home $\bigcirc$ Caregiver's place
20. What type of community does your family live in?
O Rural
Suburban
Urban / City

\section{Describe your household:}
O 2-parent
Single parent
Extended family
Other (Please specify) 
22. What is your annual average household income?

$\bigcirc$ Less than $\$ 35,000 \quad \bigcirc \$ 35,000$ - $\$ 49,999 \quad \bigcirc \$ 50,000$ - $\$ 74,999 \quad \bigcirc \$ 75,000$ or above

23. What type of dental insurance does your child have?

O Private insurance - such as through an employer or an individual/family policy you purchased on your own

Public insurance( Medicaid/Health Choice)

No dental insurance

24. What type of medical insurance does your child have?

Private insurance - such as through an employer or an individual/family policy you purchased on your own

$\bigcirc$ Public insurance( Medicaid/Health Choice) $\quad$ No medical insurance

25. What is your educational level?

$\bigcirc$ Didn't complete High School $\bigcirc$ High School Graduate or Graduate-Equivalent Diploma

O 2 year degree or some College (including Community College, Technical School)
Completed College
$\bigcirc$ Other (Please specify)

26. About how long has it been since you last visited a dentist?
O 6 months or less
More than 1 year, but not more than 3 years ago
More than 6 months, but not more than 1 year ago
Never been to a dentist
More than 3 years ago
O Don't know / Don't remember

27. Are there difficulties in carrying out oral hygiene procedures for the child? $\quad \bigcirc$ Yes $\bigcirc$ No

28. On a scale from 1 to 10 , how cooperative do you think your child is with dental procedures?

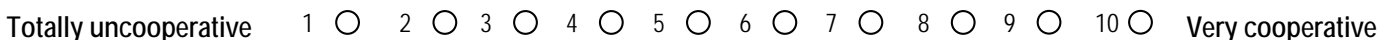

29. Do you think dental health is important? $\quad$ Y Yes O No

30. In your opinion, what is the status of your child's dental health?
Excellent
$\bigcirc$ Very good
$\bigcirc$ Good
Fair
Poor $\quad \mathrm{O}$ Has no natural teeth

31. During the past 6 months, did your child have a toothache?

Yes $\bigcirc$ No $\bigcirc$ Don't know / don't remember

32. During the past 6 months, was there a time when your child needed dental care but could not get it at that time? $\bigcirc$ Yes $\bigcirc$ No (PLEASE SKIP TO QUESTION 34) O Don't know / Don't remember (PLEASE SKIP TO QUESTION 34)

33. The last time that your child could not get the dental care helshe needed, what were the main reasons helshe could not get care? (Please choose ALL that apply)

Could not afford it

Dentist does not accept Medicaid/insurance

No way to get there (transportation problems)

There are other things in the family to be taken care of

Wait too long in clinic / office

Didn't know where to go

Patient's medical condition

My child is uncooperative

Other reason (Please specify)
No insurance

No dentist available

Health of another family member

Hours not convenient due to work

Difficulty in getting appointment

Don't like / trust / believe in dentists

Speak a different language

My child is too young 
35. If your child has never received dental care, what are the main reasons your child has never received dental care? (Please choose ALL that apply)
Could not afford it
No insurance
Dentist does not accept Medicaid/insurance
No dentist available
No way to get there (transportation problems)
Health of another family member
There are other things in the family to be taken care of
Hours not convenient due to work
Wait too long in clinic / office
Difficulty in getting appointment
Didn't know where to go
Baby teeth will "fall out" by themselves soon
Don't like / trust / believe in dentists
Child's medical condition
$\bigcirc$ Speak a different language
My child is likely to be uncooperative
My child is too young
My child's oral health is very good and does not need to see a dentist
My child's dental condition is not serious enough to see a dentist
$\bigcirc$ Other reason (Please specify)

\section{PLEASE SKIP TO QUESTION 41}

\section{About how long has it been since your child last visited a dentist?}
O 6 months or less
More than 6 months, but not more than 1 year ago
More than 1 year, but not more than 3 years ago
More than 3 years ago
O Don't know / Don't remember

37. Why did your child go to the dentist for the most recent visit?
Check-up, examination or cleaning
Something was wrong, bothering or hurting
Went for treatment of a condtion that dentist discovered at earlier check-up or examination
Don't know / don't remember
$\bigcirc$ Other (Please specify)

\section{What were the main problems faced during your child's most recent dental visit? (Please choose ALL that apply)}
$\bigcirc$ Dentist and/or assistant was not able to handle my child
$\bigcirc$ Dentist and/or assistant did not treat me or my child with respect
Dentist does not regularly treat young children
Dentist does not regularly treat special needs children
My child could not cooperate
$\bigcirc$ Dentist does not accept Medicaid
Clinic was not "special-needs" friendly
Other (Please specify)

39. How often does your child visit the dentist?
$\bigcirc$ Every 3 months
$\bigcirc$ Every 6 months
Once a year
Only when pain occurs
Other (Please specify)

\section{What type of dental office does your child go to for dental care?}
$\bigcirc$ General Practice
Pediatric Dentistry
$\bigcirc$ Hospital Dental Clinic
Health Department
Other (Please specify) 
ID:
41. What is your child's gender?
O Male
Female

42. What is your child's ethnicity?

Hispanic or Latino

Not Hispanic or Latino

43. What is your child's race?

American Indian / Alaska Native

Asian

Native Hawaiian / Other Pacific Islander

O Black / African American

White / Caucasian

Multi-racial

Other (Please specify)

Thank you for participating in this survey.

Your opinion is much valued and appreciated in improving dental care access for children. Please mail this survey back in the envelope provided.

Thank You! 
Appendix B: Sample questionnaire (Spanish)

\section{UNC DEPARTMENT OF PEDIATRIC DENTISTRY Access to Dental Care for Children with Autistic Spectrum Disorder}

INSTRUCCIONES: Use un bolígrafo para completar el formulario. Por favor sombrear la opción mas apropiada o llene los espacios en blancos según sea necesario. Por favor sombrear solamente UNA de las opciones para cada pregunta, a menos que se especifique de otra manera.

La encuesta debe ser completada por el cuidador primario. El cuidador primario se define como el adulto responsable de coordinar el cuidado dental del niño, y que se identifica así mismo/a como tal. En este caso el cuidador primario puede ser uno de los padres, abuelo, tío, tía o custodio.

Cuando múltiples individuos son responsables por el cuidado del niño/a, se usará el individuo que se considera a el/ella mismo como el cuidador primario para los asuntos relacionados con la salud oral. Todas las referencias que se hagan del cuidador primario subsecuentemente asumirán esta definición.

1. ¿Qué relación tiene con el niño? (seleccione todos los que aplican)

O Padre/madre $\bigcirc$ Custodio legal $\bigcirc$ Abuelo/a $\bigcirc$ Otro ( Por favor especifique)

2. ¿Cuántos niños (menores de 18 años) viven en el hogar? Si no tiene ninguno, ponga cero.

3. ¿Tiene en su hogar niños que han sido diagnosticados con Trastornos del Espectro de Autismo?

$\bigcirc \mathrm{Si} \quad \bigcirc$ No (Gracias por su tiempo. Esta encuesta es sólo para hogares que tienen niños con autismo. Por favor, regrese lo papeles en el sobre de retorno.)

4. ¿Cuantos de sus hijos han sido diagnosticados con trastornos del espectro de autismo (ASD por sus siglas en ingles)? Escriba el número en la casilla

5. ¿Cuáles de los siguientes diagnósticos le han dado a su hijola? Si tiene más de un niño con ASD, responda de acuerdo con el niño mayor.

Trastorno autista (autismo clásico) $\bigcirc$ Trastorno de Asperger

Trastorno dominante del desarrollo — sin que se dé otra especificación (PDD-NOS)

6. Si tiene más de un niñola con ASD, ¿cuál es el diagnóstico de el niñola que le sigue en edad?

O Solo un niño afectado - No se aplica $\bigcirc$ Trastorno autista $\bigcirc$ Trastorno de Asperger $\bigcirc$ PDD-NOS

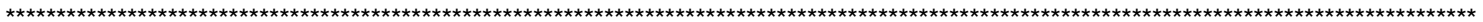

El resto de las preguntas se refieren a su hijo/a mayor con ASD - el niñola que mencionó en la pregunta 5

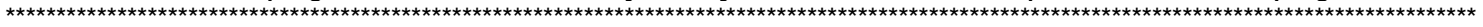

7. ¿Cuál es la severidad del diagnostico de ASD en la actualidad? $\bigcirc$ leve $\bigcirc$ moderado $\bigcirc$ severo $\bigcirc$ no esta seguro/a

\begin{tabular}{l|l|l|} 
8. ¿Cual es la edad de su hijo? & años de edad (redondear a la edad más cercana)
\end{tabular}

9. ¿A qué edad fue diagnosticado su hijo/a con ASD? años de edad (redondear a la edad más cercana)

10. Tiene su hijo alguna otra condición médica?

O No

O Si (Por favor especifique) 
11. En la actualidad, ¿esta su hijo tomando algún medicamento que se le ha recetado?

O No

O Sí (Por favor escriba el nombre del medicamento y la razón por la que lo necesita)

12. ¿En el pasado, ha tomado su hijo algún (otro) medicamento que se le ha recetado?

O No

O Sí (Por favor escriba el nombre del medicamento y la razón por la que lo necesita)

O Si O No - POR FAVOR SALTE A LA PREGUNTA 15

14. ¿Por qué razón se atiende su niño con el médico familiar? $\bigcirc$ Chequeos regulares $\bigcirc$ Enfermedades solamente $\bigcirc$ Ambos

15. ¿Está su hijo registrado en alguna de las siguientes organizaciones? Por favor seleccione TODAS las opciones que aplican

Sociedad de Autismo de Carolina del Norte

$\mathrm{O}$ TEACCH

Centro Clínico para el Estudio del Desarrollo y Aprendizaje

Otro organización relacionada con la condición de ASD de su hijo (Por favor especifique: )

16. ¿Asiste su hijola a la escuela (incluyendo educación preescolar o pre-kinder)?

O SI O No -POR FAVOR SALTE A LA PREGUNTA 18

17. ¿Qué servicios educativos recibe su hijola en la escuela? Por favor seleccione TODAS las opciones que aplican
Ninguno
Programa Educativo Personalizado
Inclusión
O Especial
O Programa Comunitario Alternativo (CAP)
Otro (Por favor especifique)
18. ¿Cuál es el nivel de educación de su hijola?
Demasiado pequeño para ir a la escuela
Preescolar o Jardín de Infancia
1ro al 3to grado
$\bigcirc$ 4to al 6 to grado
7to al 9no grado
O $10 \mathrm{mo}$ al 12vo grado
Se ha retirado de la escuela

19. ¿Donde vive su hijo? $\bigcirc$ En la casa $\bigcirc$ Institución de cuidado $\bigcirc$ Casa de Grupo $\bigcirc$ con la persona que lo cuida

20. ¿En qué tipo de comunidad vive su familia? $\quad$ Rural $\bigcirc$ Suburbana $\bigcirc$ Urbana / Ciudad

21. Describa su hogar:
O 2 padres
Padre o madre soltero
Parientes
Otro (Por favor especifique)

22. ¿Cuál es el ingreso anual de su hogar?

Menos de $\$ 35,000$ ○ $\$ 35,000$ a $\$ 49,999$ ○ De $\$ 50,000$ a $\$ 74,999$ ○ $\$ 75,000$ o más 
23. ¿Qué tipo de seguro dental tiene su niño?

O Seguro Privado - ya sea ofrecido por medio de un empleador 0 una póliza familiar 0 individual que tenga por su cuenta

O Seguro Estatal - Medicaid/Health choice

O No tiene seguro

24. ¿Qué tipo de seguro médico tiene su niño?

O Seguro Privado - ya sea ofrecido por medio de su empleador o una póliza familiar o individual que tenga por su cuenta

O Seguro Estatal - Medicaid/Health choice $\bigcirc$ No tiene seguro medico

25.¿Cuál es su nivel de educación?

No completó la escuela secundaria

$\bigcirc$ Graduado de secundaria o certificado de constancia de estudios secundarios o de preparatoria.

$\bigcirc$ Certificado de carrera de 2 años o algunos estudios universitarios (incluyendo colegios comunitarios y escuelas técnicas)

Completó estudios universitarios

Otros (Por favor especifique)

26. ¿Cuánto tiempo ha pasado desde la ultima vez que usted visitó al dentista?
O 6 meses o menos
Mas de 6 meses, pero menos de un año
$\bigcirc$ Mas de un año, pero menos de 3 años
$\bigcirc$ Hace mas de 3 años
Nunca ha ido
No sabe/ no recuerda

27. ¿Existen dificultades en llevar a cabo los procedimientos de higiene dental del niño?

$\mathrm{OSi} \mathrm{ONo}$

28. En una escala del 1 al 10, ¿Qué tanto piensa usted, que su niño coopera con los procedimientos dentales?

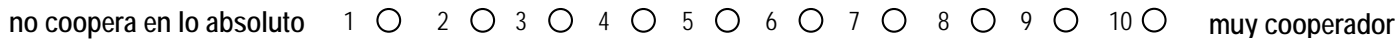

29. ¿Piensa usted que la salud oral es importante? $\quad$ Y Yes O No

30. ¿En su opinión, cuál es el estado de la salud oral de su niño?

$\bigcirc$ Excelente $\bigcirc$ muy bueno $\bigcirc$ Bueno $\bigcirc$ Neutral $\bigcirc$ Pobre $\bigcirc$ No tiene dientes verdaderos

31. Durante los últimos 6 meses, ¿ha tenido su hijo dolor de dientes? $\mathrm{OSi}$ ○ No $\bigcirc$ No sabe/ No recuerda

32. Durante los últimos 6 meses, ¿hubo alguna ocasión en que su hijo tuvo necesidad de recibir cuidado dental pero no pudo obtenerlo?

O Si O No -POR FAVOR SALTE A LA PREGUNTA $34 \quad \bigcirc$ No sabe/ No recuerda - POR FAVOR SALTE A LA PREGUNTA 34

33. La ultima vez que su hijola no obtuvo el cuidado dental que necesitaba, ¿cuáles fueron las razones principales por la que no pudo conseguirlo? (Por favor marque todas las opciones que apliquen)

Falta de recursos necesarios para pagar

O No tenía seguro

El dentista no acepta Medicaid/ seguro

No hay dentista disponible

O No tuvo como llegar (problemas de transporte)

Problemas de salud de otro miembro de la familia

Tuvo otros asuntos familiares que atender

O Las horas no le convenían debido a su trabajo

La espera es muy larga en la clínica /oficina

Dificultad para conseguir cita

No sabia a donde ir

No le gusta/ confía/ cree en los dentistas

Condición medica del paciente

O Habla un idioma diferente que el dentista

O Mi hijo/a no colabora

Mi hijo/a es muy pequeño o joven

Otra razón (Por favor especifique) 
35. Si su niño nunca ha recibido cuidados dentales, ¿cuáles son las razones principales por la que su niño nunca ha recibido cuidado dental? (Marque todas las opciones que aplican)
No tiene los recursos necesarios para pagar
No tiene seguro
El dentista no acepta Medicaid / seguro
No hay dentistas disponibles
No tiene como llegar (problemas de transporte)
$\bigcirc$ La salud de otro miembro de la familia
$\bigcirc$ Hay otros asuntos familiares que atender
Las horas no le convienen debido a su trabajo
O La espera es muy larga en la clínica / oficina
Dificultad para conseguir citas
No sabia donde ir
O Los dientes de leche se le van a caer por si solos muy pronto
No le gusta/ confía/ cree en los dentistas
$\bigcirc$ La condición medica del paciente
$\bigcirc$ Habla un idioma diferente que el dentista
Es probable que mi hijo no colabore

Mi hijo/a es muy pequeño

$\bigcirc$ La salud oral de mi niño es muy buena y no necesita ver al dentista

La condición dental de mi niño no es tan seria como para que lo tenga que ver un dentista

Otra razón (Por favor especifique)

\section{POR FAVOR SALTE A LA PREGUNTA 41}

36. ¿Cuánto tiempo ha pasado desde la última vez que su niño visitó al dentista?
O 6 meses o menos
Mas de 6 meses, pero menos de un año
Mas de un año, pero menos de 3 años
Hace mas de 3 años
O No sabe/ No recuerda

37. ¿Cuál fue la razón por la que su niño fue al dentista en su visita mas reciente?
O Chequeo, examen o limpieza
Algo estaba mal, tenía molestias o dolor
O Fue para que le hicieran el tratamiento de alguna condición que el dentista descubrió en un chequeo o examen anterior
O No sabe/ No recuerda Otro
Otro (Por favor especifique)

38. ¿Cuál fue el problema principal que tuvo que afrontar durante la ultima visita de su niño al dentista? (Por favor marque todas las opciones que aplican)

O El Dentista y/o su asistente no pudo/pudieron controlar a mi niño

O El dentista y su asistente no me trataron a mi o a mi niño con respeto

El dentista no atiende a niños con necesidades especiales

El dentista no atiende niños pequeños regularmente

El dentista no acepta el Medicaid

La clínica no esta equipada para atender a personas con necesidades especiales

Otra (Por favor especifique)

39. ¿Qué tan seguido visita su niño al dentista?
$\bigcirc$ Cada 3 meses
Cada 6 meses
Una vez al año
Solo cuando tiene dolor
Otro (Por favor especifique)

40. ¿Qué tipo de clínica dental atiende a su niño para su cuidado dental?
$O$ Dentista general
O Dentista Pediátrico
Clínica Dental del Hospital
Departamento de Salud
Otro (Por favor especifique 


\begin{tabular}{|c|c|c|}
\hline 41. ¿Cuál es el género de su hijo? & \multicolumn{2}{|c|}{ Femenino } \\
\hline 42. ¿Cuál es el origen étnico de su hijo? & Hispano o Latino & O No Hispano o Latino \\
\hline \multicolumn{3}{|l|}{ 43. ¿Cuál es la raza de su hijo? } \\
\hline Indio Americano / Nativo de Alaska & Asiático & Nativo de Hawai o de alguna Isla del Pacifico \\
\hline Negro / Afro-americano & Blanco & Múltiples razas \\
\hline Otro (Por favor especifique & & \\
\hline
\end{tabular}

Gracias por su participación en esta encuesta.

Valoramos y apreciamos mucho su opinión para mejorar la accesibilidad a los servicios dentales para los niños Por favor, envíenos la encuesta por correo en el sobre que hemos adjuntado.

Gracias! 


\section{References}

1. American psychiatric association. diagnostic and statistical manual of mental disorders. $4^{\text {th }}$ ed. washington, DC: American psychiatric association; 2000. .

2. American academy of pediatric dentistry reference manual 2010-2011. Pediatr Dent. 2010 2011;32(6 Reference Manual):1-334.

3. Rapin I, Tuchman RF. Autism: Definition, neurobiology, screening, diagnosis. Pediatr Clin North Am. 2008 Oct;55(5):1129,46, viii.

4. Bryson SE. Brief report: Epidemiology of autism. J Autism Dev Disord. 1996 Apr;26(2):165-7.

5. Wing L, Yeates SR, Brierley LM, Gould J. The prevalence of early childhood autism:

Comparison of administrative and epidemiological studies. Psychol Med. 1976 Feb;6(1):89-100.

6. Autism and Developmental Disabilities Monitoring Network Surveillance Year 2006 Principal Investigators, Centers for Disease Control and Prevention (CDC). Prevalence of autism spectrum disorders - autism and developmental disabilities monitoring network, united states, 2006.

MMWR Surveill Summ. 2009 Dec 18;58(10):1-20.

7. Barbaresi WJ, Katusic SK, Colligan RC, Weaver AL, Jacobsen SJ. The incidence of autism in olmsted county, minnesota, 1976-1997: Results from a population-based study. Arch Pediatr Adolesc Med. 2005 Jan;159(1):37-44.

8. Nassar N, Dixon G, Bourke J, Bower C, Glasson E, de Klerk N, et al. Autism spectrum disorders in young children: Effect of changes in diagnostic practices. Int J Epidemiol. 2009 Oct;38(5):1245-54.

9. Charles JM. Dental care in children with developmental disabilities: Attention deficit disorder, intellectual disabilities, and autism. J Dent Child (Chic). 2010 May-Aug;77(2):84-91.

10. Idaira Y, Nomura Y, Tamaki Y, Katsumura S, Kodama S, Kurata K, et al. Factors affecting the oral condition of patients with severe motor and intellectual disabilities. Oral Dis. 2008 Jul;14(5):435-9.

11. Bissar AR, Kaschke I, Schulte AG. Oral health in 12- to 17-year-old athletes participating in the german special olympics. Int J Paediatr Dent. 2010 Jul 18.

12. Desai M, Messer LB, Calache H. A study of the dental treatment needs of children with disabilities in melbourne, australia. Aust Dent J. 2001 Mar;46(1):41-50.

13. Hennequin M, Allison PJ, Veyrune JL. Prevalence of oral health problems in a group of individuals with down syndrome in france. Dev Med Child Neurol. 2000 Oct;42(10):691-8.

14. Davidovich E, Aframian DJ, Shapira J, Peretz B. A comparison of the sialochemistry, oral pH, and oral health status of down syndrome children to healthy children. Int J Paediatr Dent. 2010 Jul;20(4):235-41. 
15. Altun C, Guven G, Akgun OM, Akkurt MD, Basak F, Akbulut E. Oral health status of disabled individuals attending special schools. Eur J Dent. 2010 Oct;4(4):361-6.

16. Barton M, Volkmar F. How commonly are known medical conditions associated with autism? J Autism Dev Disord. 1998 Aug;28(4):273-8.

17. Gillberg C, Billstedt E. Autism and asperger syndrome: Coexistence with other clinical disorders. Acta Psychiatr Scand. 2000 Nov;102(5):321-30.

18. Autism spectrum disorders (pervasive developmental disorders) [Internet]. Available from: http://www.nimh.nih.gov.libproxy.lib.unc.edu/health/publications/autism/completeindex.shtml. Accessed October 11, 2010.

19. Hernandez PJ. Perspectives of a parent and a provider for children with special health care needs. Pediatr Dent. 2007 Mar-Apr;29(2):105-7.

20. Lowe O, Lindemann R. Assessment of the autistic patient's dental needs and ability to undergo dental examination. ASDC J Dent Child. 1985 Jan-Feb;52(1):29-35.

21. Kopycka-Kedzierawski DT, Auinger P. Dental needs and status of autistic children: Results from the national survey of children's health. Pediatr Dent. 2008 Jan-Feb;30(1):54-8.

22. Shapira J, Mann J, Tamari I, Mester R, Knobler H, Yoeli Y, et al. Oral health status and dental needs of an autistic population of children and young adults. Spec Care Dentist. 1989 MarApr;9(2):38-41.

23. Morinushi T, Ueda Y, Tanaka C. Autistic children: Experience and severity of dental caries between 1980 and 1995 in kagoshima city, japan. J Clin Pediatr Dent. 2001 Summer;25(4):323-8.

24. DeMattei R, Cuvo A, Maurizio S. Oral assessment of children with an autism spectrum disorder. J Dent Hyg. 2007 Summer;81(3):65.

25. Marshall J, Sheller B, Mancl L. Caries-risk assessment and caries status of children with autism. Pediatr Dent. 2010 Jan-Feb;32(1):69-75.

26. US Department of Health and Human Services. Healthy People 2020 - Proposed Objectives Available at: "Http://www.Healthypeople.gov/hp2020/objectives/TopicArea.Aspx?id=10\&TopicArea=Access+ to+Health+Services". Accessed August 23, 2010. .

27. Seale NS, Casamassimo PS. Access to dental care for children in the united states: A survey of general practitioners. J Am Dent Assoc. 2003 Dec;134(12):1630-40.

28. Mofidi M, Rozier RG, King RS. Problems with access to dental care for medicaid-insured children: What caregivers think. Am J Public Health. 2002 Jan;92(1):53-8.

29. Byck GR, Walton SM, Cooksey JA. Access to dental care services for medicaid children: Variations by urban/rural categories in illinois. J Rural Health. 2002 Fall;18(4):512-20. 
30. American dental association (ADA) state and community models for improving access to dental care for the underserved - A white paper. october 2004.

31. Edelstein BL. Disparities in oral health and access to care: Findings of national surveys. Ambul Pediatr. 2002 Mar-Apr;2(2 Suppl):141-7.

32. Al Agili DE, Bronstein JM, Greene-McIntyre M. Access and utilization of dental services by alabama medicaid-enrolled children: A parent perspective. Pediatr Dent. 2005 Sep-Oct;27(5):41421.

33. Smith RG, Lewis CW. Availability of dental appointments for young children in king county, washington: Implications for access to care. Pediatr Dent. 2005 May-Jun;27(3):207-11.

34. Newacheck PW, McManus M, Fox HB, Hung YY, Halfon N. Access to health care for children with special health care needs. Pediatrics. 2000 Apr;105(4 Pt 1):760-6.

35. Mayer ML, Skinner AC, Slifkin RT, National Survey of Children With Special Health Care Needs. Unmet need for routine and specialty care: Data from the national survey of children with special health care needs. Pediatrics. 2004 Feb;113(2):e109-15.

36. Kane D, Mosca N, Zotti M, Schwalberg R. Factors associated with access to dental care for children with special health care needs. J Am Dent Assoc. 2008 Mar;139(3):326-33.

37. White PH. Access to health care: Health insurance considerations for young adults with special health care needs/disabilities. Pediatrics. 2002 Dec;110(6 Pt 2):1328-35.

38. Kane DJ, Zotti ME, Rosenberg D. Factors associated with health care access for mississippi children with special health care needs. Matern Child Health J. 2005 Jun;9(2 Suppl):S23-31.

39. Kogan MD, Strickland BB, Blumberg SJ, Singh GK, Perrin JM, van Dyck PC. A national profile of the health care experiences and family impact of autism spectrum disorder among children in the united states, 2005-2006. Pediatrics. 2008 Dec;122(6):e1149-58.

40. Manning-Courtney P. Addressing the crisis in access to autism treatment using health care improvement science. Arch Pediatr Adolesc Med. 2007 Apr;161(4):414-5.

41. Thomas KC, Ellis AR, McLaurin C, Daniels J, Morrissey JP. Access to care for autism-related services. J Autism Dev Disord. 2007 Nov;37(10):1902-12.

42. Birkin C, Anderson A, Seymour F, Moore DW. A parent-focused early intervention program for autism: Who gets access? J Intellect Dev Disabil. 2008 Jun;33(2):108-16.

43. Liptak GS, Benzoni LB, Mruzek DW, Nolan KW, Thingvoll MA, Wade CM, et al. Disparities in diagnosis and access to health services for children with autism: Data from the national survey of children's health. J Dev Behav Pediatr. 2008 Jun;29(3):152-60.

44. Newacheck PW, Hughes DC, Hung YY, Wong S, Stoddard JJ. The unmet health needs of america's children. Pediatrics. 2000 Apr;105(4 Pt 2):989-97. 
45. Yu SM, Bellamy HA, Kogan MD, Dunbar JL, Schwalberg RH, Schuster MA. Factors that influence receipt of recommended preventive pediatric health and dental care. Pediatrics. 2002 Dec;110(6):e73.

46. Wang H, Norton EC, Rozier RG. Effects of the state children's health insurance program on access to dental care and use of dental services. Health Serv Res. 2007 Aug;42(4):1544-63.

47. Lee JY, Rozier RG, Norton EC, Kotch JB, Vann WF,Jr. Effects of WIC participation on children's use of oral health services. Am J Public Health. 2004 May;94(5):772-7.

48. Yu SM, Bellamy HA, Schwalberg RH, Drum MA. Factors associated with use of preventive dental and health services among U.S. adolescents. J Adolesc Health. 2001 Dec;29(6):395-405.

49. Lewis C, Robertson AS, Phelps S. Unmet dental care needs among children with special health care needs: Implications for the medical home. Pediatrics. 2005 Sep;116(3):e426-31.

50. Lewis CW. Dental care and children with special health care needs: A population-based perspective. Acad Pediatr. 2009 Nov-Dec;9(6):420-6.

51. Nelson LP, Getzin A, Graham D, Zhou J, Wagle EM, McQuiston J, et al. Unmet dental needs and barriers to care for children with significant special health care needs. Pediatr Dent. 2011 2011-01-01;33(1):29,30,31,32,33,34,35,36.

52. Brickhouse TH, Farrington FH, Best AM, Ellsworth CW. Barriers to dental care for children in virginia with autism spectrum disorders. J Dent Child (Chic). 2009 Sep-Dec;76(3):188-93.

53. Aday LA, Andersen R. A framework for the study of access to medical care. Health Serv Res. 1974 Fall;9(3):208-20.

54. Burns KE, Duffett M, Kho ME, Meade MO, Adhikari NK, Sinuff T, et al. A guide for the design and conduct of self-administered surveys of clinicians. CMAJ. 2008 Jul 29;179(3):245-52.

55. Vainio L, Krause M, Inglehart MR. Patients with special needs: Dental students' educational experiences, attitudes, and behavior. J Dent Educ. 2011 Jan;75(1):13-22.

56. Wolff AJ, Waldman HB, Milano M, Perlman SP. Dental students' experiences with and attitudes toward people with mental retardation. J Am Dent Assoc. 2004 Mar;135(3):353-7.

57. Weil TN, Inglehart MR. Dental education and dentists' attitudes and behavior concerning patients with autism. J Dent Educ. 2010 Dec;74(12):1294-307. 